\title{
Gabino Palomares: A History of Canto Nuevo in Mexico
}

\author{
CLAUDIO PALOMARES-SALAS \\ TRANSLATED BY SILVIO J. DOS SANTOS
}

The civil wars, military coups, dictatorships, and revolutions that marked the histories of Cuba, Argentina, Chile, Brazil, and Uruguay during the second half of the twentieth century propelled the socially-engaged singers of the Nueva Canción to stardom, granting them a privileged place in the emotional tales of the nation. ${ }^{1}$ In Mexico, the story was different. Without a clearly articulated narrative of oppression and violence, the voices of resistance did not find a place in the national affective imagination. While figures such as Silvio Rodríguez and Mercedes Sosa managed to convince a sector of the Mexican public to stand in solidarity with the oppressed peoples of Latin America, figures such as Amparo Ochoa, Óscar Chávez, and Gabino Palomares did not succeed-apparently-in convincing the Mexican public that there were also reasons to protest in Mexico. ${ }^{2}$

The story of modern Mexican troubadours is absent from the annals of history. It exists as scattered references in newspapers, as anecdotes, and as a collection of songs sung in a disorganized manner by a group relegated to the margins of the cultural landscape. It is, nevertheless, a story of resistance whose heroes_singers, songwriters, and performers—spent the decades between 1960 and 1990 denouncing poverty and corruption, condemning governmental violence, marching side by side with students, activists, women, workers, and peasants, and supporting civil rights and grassroots movements both nationally and internationally.

The story of these musicians has remained unknown for too long. This article attempts to reignite academic interest in this story with the goal of encouraging future critical and theoretical studies regarding socially-engaged Mexican singers and songwriters from the 1960s through the 1990s. It focuses on the life and work of one of the main exponents of the Mexican protest song, singer-songwriter Gabino Palomares (b. 1950), whose work is essential to our understanding of the contemporary cultural history of Mexico.

\section{The Latin American Nueva Canción}

The direct antecedent of the Latin American protest song is the folklorist movement that gained strength in the continent as a response to the international commercial offerings imposed by American and Latin American mainstream media since the end of the 1950s. ${ }^{3}$ This movement was initially nourished by interest in the music and culture of the indigenous peoples of the American continent, which emerged during the same period in Europe, especially in Paris, and which led to the dissemination of works by

\footnotetext{
${ }^{1}$ Note on translation: The translator has retained the original terms Nueva Canción and Canto Nuevo in Spanish for the sake of clarity. Both terms can be translated into English as "New Song."

${ }^{2}$ On the social and musical characteristics of the New Song, which contributed to its growth and acceptance all over Latin America, see Fernando Reyes Matta, "The New Song and Its Confrontation in Latin America," in Marxism and the Interpretation of Culture, ed. Cary Nelson and Lawrence Grossberg (Urbana: University of Illinois Press, 1988): $448-449$. ${ }^{3}$ Salvador Ojeda, "Panorama del Canto Nuevo en México," in Diálogos: artes, letras, ciencias humanas 15, no. 2 (March-April 1979): 24, http://www.jstor.org/stable/27934254.
} 
artists such as Violeta Parra, Atahualpa Yupanqui, and some years later Mercedes Sosa.

As a political art form, Nueva Canción was the result of the East-West global polarization of the Cold War and the international anti-imperialist, anti-colonialist, and anti-communist rhetoric it engendered. It was also an outcome of the Cuban Revolution (1959), military dictatorships in the Southern Cone (1973-1982), and civil wars in Guatemala (1960-1996), Nicaragua (1960-1990), and El Salvador (1980-1992). The fall of the Berlin Wall in 1989 and the subsequent collapse of the Soviet Union in 1991 marked the end of the social, cultural, and political structures that facilitated the development of the movement in the first place. Many songwriters and interpreters of the Nueva Canción are still active, and their songs are as relevant today as they were in the past, for none of the injustices they denounce have been resolved. Nevertheless, since the 1990s, the Nueva Canción movement ceased to be something new and had to give way to other forms of literary and musical expression that, if on the one hand were still concerned with denouncing social injustices (as was the case with the rock en español movement), on the other hand distanced themselves from the socially-engaged and highly disciplined political formation of their predecessors. ${ }^{4}$ On this Palomares has said: "I would have loved it if my songs went out of fashion. It is what I most wish, because then I would be able to say that the problems I address have been resolved... but they are still relevant. The social and political problems I address have not been overcome."

The forerunners of the Nueva Canción movement were Violeta Parra (Chile, 1918-1967) and Atahualpa Yupanqui (Argentina, 1908-1992), each with a style of their own, ${ }^{6}$ followed immediately by Mercedes Sosa (Argentina, 1935-2009), the most beloved and respected interpreter of the movement. ${ }^{7}$

We can mark the beginning of Nueva Canción in Latin America with the appearance of the Nuevo Cancionero Argentino (The New Argentinian Song Repertoire), a manifesto signed in Mendoza on February 11, 1963, by Manuel Óscar Matus, Armando Tejada Gómez, Pedro Horacio Tusoli, Tito Francia, Juan Carlos Sedero, Victor Nieto, and Mercedes Sosa herself. This manifesto laid the foundation for all Nueva Canción movements in Latin America, for it called for a revaluation and a revalorization of the country's folkloric traditions and the inclusion of new lyrical contents which expressed the dreams, struggles, and hopes of the people. ${ }^{8}$ Besides the signatories to the manifesto, other musicians that became important examples of the Nueva Canción in Argentina were Nacha Guevara (b. 1940), César Isella (b. 1938), Horacio Guarany (1925-2017), Victor Heredia (b. 1947), and León Gieco (b. 1951). ${ }^{9}$

In Chile, the Nueva Canción Chilena was a lyrical and musical trend that also emerged in the 1960s

\footnotetext{
${ }^{4}$ For a broad historical and contemporary perspective of the rock scene in Latin America, see Deborah Pacini Hernandez, Hector Fernández L'Hoeste, and Eric Zolov, Rockin' Las Américas: The Global Politics of Rock in Latin/o America (Pittsburgh: University of Pittsburgh Press, 2004).

5 Arturo Cruz Bárcenas, "Celebra Gabino Palomares 35 años de canto social,” in La fornada (July 13, 2007), http://www.jornada.unam.mx/2007/07/13/index.php?section=espectaculos\&article=a11n1esp.

${ }^{6}$ For a study of the life and work of Violeta Parra, see Lorna Dillon, Violeta Parra: Life and Work. (Rochester: Tamesis Books, 2017). For a careful study on the role played by Atahualpa Yupanqui in promoting traditional music from the southern Cone, see Carlos Molinero and Pablo Vila, "Atahualpa Yupanqui: The Latin American Precursor of the Latin American Song Movement," in The Militant Song Movement in Latin America: Chile, Uruguay, and Argentina, ed. Pablo Vila (Lanham, MD: Lexington Books, 2014): 163-92.

${ }^{7}$ For a concise review of Sosa's work and relevance in the Nueva Canción movement, see Matthew B. Karush, "Indigenous Argentina and Revolutionary Latin America: Mercedes Sosa and the Multiple Meanings of Folk Music," in Musicians in Transit: Argentina and the Globalization of Popular Music (Durham: Duke University Press, 2017): 142-178.

${ }^{8}$ See Claudio Díaz, "The Nuevo Cancionero Movement: A Change of Paradigm in Argentine Folklore," in A Latin American Music Reader: Views from the South, ed. Javier F. León and Helena Simonett, (Urbana: University of Illinois Press, 2016): n.p.

${ }^{9}$ See Carlos Molinero and Pablo Villa, "A brief history of the militant song movement in Argentina," in The Militant Song Movement in Latin America: Chile, Uruguay, and Argentina, ed. Pablo Vila (Lanham, MD: Lexington Books, 2014): 193228.
} 
and ended abruptly in 1973 after Pinochet's military coup. Its main exponents were Víctor Jara (19321973), cowardly killed in the early days of the coup, Isabel Parra (b. 1939), Ángel Parra (b. 1943), Patricio Manns (b. 1937), and the groups Inti-Illimani (fl. 1967) and Quilapayún (fl. 1965). It is also important to give credit to the folklorist and promoter of Chilean culture René Largo Farías, who gave cohesion to the movement through projects such as the Chile Laughs and Sings Festival. After 1973, the Chilean New Song was kept alive by some of its members in exile. ${ }^{10}$

Out of the Cuban Revolution emerged Nueva Trova, a movement parallel to the Nueva Canción, but whose members were not singing against their government but backed by it, often in very problematic ways. The cultural state apparatus of revolutionary Cuba turned members of the Nueva Trova into celebrated stars who traveled all over Latin America spreading the anti-imperialist, pro-revolutionary rhetoric manufactured on the island. Its main exponents were Silvio Rodríguez (b. 1946), the most outstanding figure of the movement and doubtless its most talented poet, Pablo Milanés (b. 1943), Noel Nicola (1946-2005), Amaury Pérez (b. 1953), Pedro Luis Ferrer (b. 1952), and Vicente Feliú (b. 1947). ${ }^{11}$

The Nueva Canción movement then spread all over Latin América. In Venezuela, Alí Primera (1941-1985), Soledad Bravo (b. 1943), and Gloria Martín (b. 1952) were its main figures. ${ }^{12}$ In Uruguay, Alfredo Zitarrosa (1936-1989) and Daniel Viglietti (1939-2017) formed the Canto Popular. ${ }^{13}$ In Peru, Chabuca Granda (1920-1983) and Nicomedes Santa Cruz (1925-1992) occupied an important position in the struggle and recognition of Afro-Peruvian music and culture. ${ }^{14}$ In Nicaragua, Carlos Mejía Godoy (b. 1943) and Luis Enrique Mejía Godoy (b. 1945) became the two most prominent Central American voices. ${ }^{15}$ In Brazil, as part of the Tropicália movement, we can mention the legendary Caetano Veloso (b. 1942), Chico Buarque (b. 1944), and Gilberto Gil (b. 1942). ${ }^{16}$ Across the Atlantic, and during Spain's transition to democracy, Joan Manuel Serrat (b. 1943), Luis Eduardo Aute (b. 1943), and Paco Ibañez (b.

\footnotetext{
${ }^{10}$ For a comprehensive history and analysis of the Nueva Canción Chilena, see Osvaldo Rodríguez Musso, La nueva canción chilena: continuidad y reflejo (La Habana: Casa de las Américas, 1988); Nancy Morris, "New Song in Chile: Half a Century of Musical Activism," in The Militant Song Movement in Latin America: Chile, Uruguay, and Argentina, ed. Pablo Vila (Lanham, MD: Lexington Books, 2014): 19-44; Jan Fairley et al., Living Politics, Making Music: The Writings of Jan Fairley (Burlington: Farnham Surrey, 2014); and Miguel Cabezas, “The Chilean 'New Song," in Index on Censorship 6.4 (2016): 3036. https://doi.org/10.1080/03064227708532673. For an up-to-date and longer study, see J. Patrice McSherry, Chilean New Song: The Political Power of Music, 1960s-1973 (Philadelphia, PA: Temple University Press, 2015).

${ }^{11}$ For an excellent critical and detailed study on Nueva Trova, see Robin Moore, "Transformations in Cuban Nueva Trova," in Ethnomusicology47, no. 1 (2003): 1-41. https://doi.org/10.2307/852510; and Robin Moore, Music and Revolution:

Cultural Change in Socialist Cuba (Berkeley: University of California Press, 2006). See also Clara Díaz, Sobre la guitarra, la voz (La Habana: Editorial Letras Cubanas, 1994).

12 See Hazel Marsh, Hugo Chávez, Alí Primera and Venezuela: The Politics of Music in Latin America (London: Palgrave Macmillan, 2016). See also Isaac López, "La 'canción protesta' en Venezuela: Una aproximación a su origen y auge (19671977)," in Humania del Sur Año 9, no. 16 (2014): 65-77. https://doi.org/10.1057/978-1-137-57968-3.

${ }^{13}$ See Abril Trigo, "Modern Foundations of Uruguayan Popular Music" in The Militant Song Movement in Latin America: Chile, Uruguay, and Argentina, ed. Pablo Vila (Lanham, MD: Lexington Books, 2014): 97-120. Also Camila Juárez, "Popular Music and the Avant-Garde in Uruguay: The Second Canto Popular Generation in the 1970s," in The Militant Song Movement in Latin America: Chile, Uruguay, and Argentina, ed. Pablo Vila (Lanham, MD: Lexington Books, 2014): 121140 .

14 See Martha Ojeda, Nicomedes Santa Cruz: Ecos de Africa en Perú (Woodbridge: Tamesis, 2003). Also Heidi Feldman, Black Rhythms of Peru: Reviving African Musical Heritage in the Black Pacific (Middletown: Wesleyan University Press, 2006).

15 See Juan Carlos Ureña, “The Mockingbird Still Calls for Arlen: Central American Songs of Rebellion 1970-2010," in Song and Social Change, ed. Lauren Shaw (New York: Lexington Books, 2013): 49-76.

${ }^{16}$ See Christopher Dunn, Brutality Garden: Tropicália and the Emergence of a Brazilian Counterculture (Chapel Hill, NC: University of North Carolina Press, 2001). For an interesting review of several albums by members of the international Nueva Canción, see Jan Fairley, “Alive and Performing in Latin America: Review,” in Popular Music 7, no. 1 (Jan 1988): 105-110. https://doi.org/10.1017/S0261143000002609.
} 
1934) emerged as the leading voices of the so-called canción protesta. ${ }^{17}$

In Mexico, the four pillars of Canto Nuevo were: the group Los Folkloristas (fl. 1966), ${ }^{18}$ Amparo Ochoa (1946-1994), ${ }^{19}$ Óscar Chávez (b. 1935), and Gabino Palomares (b. 1950). They all occupied a privileged position within the international Nueva Canción movement, sharing stages and friendship with leading figures from the rest of the continent and representing Mexico on the global map of the protest song. ${ }^{20}$

The aforementioned international collective of singers and songwriters constitute what we can call the generation of the international Nueva Canción, a movement active between 1960 and 1991.

\section{Canto Nuevo in Mexico}

Canto Nuevo was the Mexican manifestation of the international Nueva Canción movement. Like the latter, it attempted to recover, reinterpret, and promote national, indigenous, and folkloric traditions in order to contribute to addressing the social, political, and economic conditions of the people. ${ }^{21}$ In El canto de la tribu, one of few studies to explore the alternative popular music movement in Mexico, Jorge $\mathrm{H}$. Velasco explains that:

In the late 1960s and early 1970s, there emerged [in Mexico] groups and singers dedicated to the collection and dissemination of old songs, the use of traditional musical instruments once restricted to regional levels, and the use of musical genres not broadcasted on commercial radio or television. Alongside this attitude of revaluation of these songs and music, by interpreting and disseminating them, there arises... the need to relate and denounce through song the social injustice under which a great sector of the population had suffered. ${ }^{22}$

Canto Nuevo was the continuation of the folklorist tradition, but it was endowed with a renewed and more disciplined, socially-engaged narrative. In the words of Salvador Ojeda, "the new [in Canto Nuevo] is the political attitude in the songs." 23 Political attitude is best expressed in songs through words rather than music, and thus, it is agreed that the socially-engaged content of the lyrics is what defines the genre and differentiates it from national folklorist movements in music and from the apolitical song

\footnotetext{
${ }^{17}$ For a discussion on the Spanish protest song, see Roberto Torres Blanco, "Canción protesta: definición de un nuevo concepto historiográfico," in Cuadernos de Historia Contemporánea 27 (2005): 223-246. See also Fernando González Lucini, Y la palabra se hizo música: La canción de autor en España (Madrid: Fundación Autor, 2006).

${ }^{18}$ For a touching and informed history of the group, see René Villanueva, Cantares de la memoria: Recuerdos de un folklorista. 25 años de historia del grupo Los Folkloristas: alma y tradición de la música popular mexicana (México, D.F: Grupo Ed. Planeta, 1994). Throughout its history, the members of Los Folkloristas have frequently changed. Those who were there from the beginning include José Ávila, René Villanueva, Gerardo Tamez, Salvador Ojeda, Emilia Domínguez, Jas Reuter, Rubén Ortiz, María Elena Torres, Rosa Elena Domínguez, Jorge Saldaña, Juan Antonio Ávila, Carlos Ávila, Emiliano Ávila, Alejandro Ávila, Sara Rosa Ávila, Carlos Alamillo, Emilia Martínez Negrete, José Luis Belmar, Efraín Trillo, Laura Cao Romero, Teresa Bourlón, Adrián Nieto, Héctor Sánchez Campero, Yocasta Gallardo, Leonor Lara, Efrén Parada, Olga Alanís, and Rosalinda Reynoso.

${ }^{19}$ See Julio Bernal, Se me reventó el barzón: Amparo Ochoa (Culiacán: Universidad Autónoma de Sinaloa, 1996).

20 There are very few studies on Mexican Canto Nuevo. Three essential readings, however, are: Salvador Ojeda, "Panorama del Canto Nuevo en México," 23-29; Jorge Velasco, El canto de la tribu (México D.F.: Conaculta, 2004); and Tanius Karam, "Notas para pensar la Nueva Canción mexicana: De Los Folkloristas a Alejandro Filio," in Humania del Sur 9 , no. 16 (January-June, 2014): 27-39.

${ }^{21}$ The interest in national music and culture led to the emergence of the group Los Folkloristas in 1966. Live recordings of their concerts at the Palacio de Bellas Artes in Mexico City immediately granted them a place as the leaders of the “educated" folklore (folclor culto) in Mexico. Los Folkloristas: Repertorio de sus conciertos en el Palacio de Bellas Artes 72 73, Discos Pueblo, México, 1974, LP.

22 Jorge H. Velasco, El canto de la tribu, 119.

${ }^{23}$ Salvador Ojeda, "Panorama del Canto Nuevo en México," 26.
} 
traditions of the continent, such as the trova, bolero, and son.

Canto Nuevo occurred during the "perfect dictatorship," as Mario Vargas Llosa has called the PRI regime. ${ }^{24}$ It was a dictatorship without a dictator, in which an institutionalized government coopted by a fossilized party remained in power for more than seventy years (1929-2000). Canto Nuevo's Mexico was the Mexico of Gustavo Díaz Ordaz (1964-1970), and the 1968 student massacre in Tlatelolco. It was the Mexico of the dirty war, where the state committed a series of atrocities in seeking to dissolve opposition. The dirty war extended through the 1970s and sheltered the mandates of Luis Echeverría (1970-1976) and José López Portillo (1976-1982). Although, on the one hand, the Echeverría government welcomed Latin American exiles who arrived fleeing the Argentine, Chilean, and Uruguayan dictatorships—an act which undoubtedly nurtured the Canto Nuevo movement—on the other hand, it had students and peasants killed in events like The Corpus Christi Massacre (El Halconazo). ${ }^{25}$ The subsequent government of Miguel de la Madrid (1982-1988) left Mexico with a legacy of corruption, economic crises, and electoral fraud. A chronicle of such events has been preserved in the musical production of the Canto Nuevo, particularly in the work of Palomares, the movement's leading lyricist.

With time, Los Folkloristas, Amparo Ochoa, Óscar Chávez, and Gabino Palomares would become the best known and most influential exponents of the Canto Nuevo movement. However, several other artists, Mexicans and non-Mexicans, all of whom shared the same political aspirations, built the tower of protest song in Mexico. They include Judith Reyes and José de Molina, the chroniclers of the 1968's student movement, León Chávez Teixeiro, Anthar and Margarita, Grupo Víctor Jara, Eugenia León, the group Los Nakos, Daniel Tuchman, Guadalupe Pineda, Guillermo Velázquez and the Leones de Xichu, Julio Solórzano, Pancho Madrigal, Marcial Alejandro and the group La Nopalera, Carlos Díaz "Caíto," Delfor Sombra, the group Sanampay, the group Canek, Tania Libertad, Tehua, and Luis Enrique Mejía Godoy. This group constitutes what we can call the generation of Canto Nuevo in Mexico. ${ }^{26}$

\section{Defining Mexican Canto Nuevo}

While it is true that the Canto Nuevo movement in Mexico had its antecedents in folklore, its development was instead a rupture from it. Despite the political and affective affinities between folklorists and protest song singers, figures such as Ochoa, Chávez, and Palomares managed to break with the aesthetic and thematic obligations of the Mexican folkloric musical tradition, paving the way for a new type of artistic expression, whose essence, as Ojeda points out, lies not in the music, but in the

\footnotetext{
24 Peruvian writer Mario Vargas Llosa made that comment during a television appearance in 1990, as part of a political panel for the colloquium "Encuentro Vuelta: La experiencia de la libertad." The panel included Mexican historian Enrique Krauze and members of the public included the poet and writer Octavio Paz. For a detailed account of the episode, see Enrique Krauze "La dictadura perfecta," in Letras Libres (November 12, 2012), http://www.letraslibres.com/mexico-espana/ladictadura-perfecta.

${ }^{25}$ On June 10, 1971, hundreds of students were mobilizing and asking for the release of political prisoners. They were also demanding the retreat of riot police from middle and higher education schools. Without warning, they were shot at by the paramilitary group known as Los Halcones (The Falcons), thus the label "El Halconazo." The event is also known as the Corpus Christi Massacre. The exact number of deaths is unknown, but estimated at dozens. It was not until Vicente Fox's administration (2000-2006) that dirty war crimes such as this began to be investigated, although those responsible still enjoy impunity.

${ }^{26}$ There were other singers who shared the values of Canto Nuevo, but whose musical production oscillated between protest song, romantic song, and rock. These included Margie Bermejo, Guillermo Briseño, and Betsy Pecanins. The Rupestres movement (a mixture of rock and trova) included Jaime López, Roberto González, José Ponce, Rafael Catana, Gerardo Enciso, and Rockdrigo González, who died in the earthquake on September 19, 1985, in Mexico City.
} 
unmistakable political message of the texts.

In the program notes for the First Festival of Latin American Nuevo Canto (1982) in Mexico, Sergio Jaber explained how the movement was understood from within in terms of both its nomenclature and lineage:

Nuevo Canto was born in the 1960s as a movement that sought to recover and renew the authentic cultural values of our peoples, offering musical alternatives that, as opposed to the ones sold by commercial companies, clearly reflect the cultural necessities in Latin America. Baptized with names such as protest, social, political, response (Contestatoria [sic]), committed, testimonial, and offering songs—and in Cuba as Nueva Trova-Nuevo Canto is essentially a young movement that, rooted in folklore and traditional music, maintains a deep connection to the social struggles waged every day throughout the entire continent. And with a sense of vindication of its own values (understood as a particular aspect of the general struggle and not as a political movement per se), Canto Nuevo acquires its form based on an infinitude of sociological aspects that, in conjunction with intense creativity supported by folkloric research, manages to channel and create poetic forms of great quality while effectively developing its musical resources and adopting all of the daily problems of our peoples. ... Its theme is the people and the people are the whole [community] that, with this movement, seeks a Latin American brotherhood. It seeks to establish a broader and more humane cultural unity, a continental unity that goes hand in hand with specifically national developments. Canto Nuevo is the legitimate artistic expression of a Latin America that strives for a more harmonious and fairer future and that, while responding to aesthetic demands, carries within a wealth of collective hope from our people to build a new man, a new world. ${ }^{27}$

The terms Canto Nuevo, Nuevo Canto and Nueva Canción have been used all over Latin America by troubadours, their audiences, and the critics and journalists who have studied the Nueva Canción movement. ${ }^{28}$ They were always used interchangeably in festivals and committees as synonyms of protest song. The term Nueva Canción, however, was the favored umbrella term used to accommodate a variety of distinct local protest song movements throughout the continent. In Mexico, Nueva Canción was most often referred to as Canto Nuevo. There is some confusion with the term, which has sometimes been used to refer to the second generation of singer-songwriters that appeared in Mexico in the 1980s and 1990s. It is sometimes thought, for example, that Canto Nuevo was a less politicized genre than Nueva Canción, and that its singers and songwriters preferred a more poetic and musically complex style that separates them from the often rudimentary and extreme left-wing rhetoric of the Nueva Canción artists. ${ }^{29}$ This appreciation, however, is incorrect. Parallel to the Canto Nuevo movement in Mexico in the 1980s, there was indeed a new generation of songwriters and interpreters who may have occasionally maintained a critical attitude toward the sociopolitical reality in Mexico, but they distanced themselves from the revolutionary ethos of the Nueva Canción. This was a logical consequence of the disenchantment toward socialist and anti-capitalist grand narratives that affected young people worldwide after the collapse of the Soviet Union. These singers and songwriters, including Alejandro Filio, Fernando Delgadillo, David Haro, and the group Mexicanto, to name a few, continued the troubadour tradition in Mexico in terms of

\footnotetext{
${ }^{27}$ Segio Jaber F, Programa del Primer Festival del Canto Nuevo Latinoamericano (México, 1982). The Festival took place between March 30 and April 4, 1982, at the National Auditorium in Mexico City. Palomares participated in this festival alongside the main protagonists of the international Nueva Canción, including Daniel Viglietti, Silvio Rodríguez, Roy Brown, Noel Nicola, Carlos and Luis Enrique Mejía Godoy, Nicomedes Santacruz, Alí Primera, and Amparo Ochoa.

${ }^{28}$ See Reyes Matta, "The New Song and Its Confrontation in Latin America," 459-460.

29 See for example, Alejandro L. Madrid, Music in Mexico: Expressing Music, Expressing Culture (New York: Oxford University Press, 2013): 115.
} 
both music and performance. They kept the iconic chair on the stage with a microphone and a guitar, but their message was not always revolutionary, nor were their audiences. For this reason, they must be considered part of a different trend or movement, for as I have explained above, what made Canto Nuevo new was precisely its highly political, left-wing rhetoric. Moreover, singer-songwriters of Canto Nuevo constitute a sort of avant-garde that, like the historical avant-gardes of the early twentieth century, aimed to integrate art into the praxis of life. ${ }^{30}$ They were not singing political songs for the applause. They were committed citizens whose everyday lives reflected the values they were singing.

The aforementioned second generation of singers and songwriters has sometimes been referred to as the generation of "la trova" or the "trova mexicana" (Mexican Trova). These terms, although more accurate than Canto Nuevo, are still problematic. Tanius Karam, one of few critics who have paid attention to the protest song movement in Mexico, explains:

We do not believe that it is possible to have a movement that we can call "Mexican Trova"even if there are CDs with this name-if by this term we mean that songwriters are organically connected and associated with recordings, themes, aesthetic principles, etc. The expression "nueva trova mexicana" (New Mexican Trova) will always be polemical. Nowadays, perhaps, the term "trova" evokes singers such as David Haro, Alejandro Filio, the duet Mexicanto (Sergio Félix and David Filio), and some others. In many cases, however, this term does not suppose a traditional link with social songs of the 1970s, nor can we define them as songwriters of denouncement and protest. ${ }^{31}$

Thus, the Canto Nuevo and Trova singers and songwriters coexisted side by side in Mexico for more than a decade, through the 1980s and early 1990s. They represent two very different approaches to the song tradition: one explicitly political, the other not. They shared a common musicality and performance, but differed in their overall message.

On what remains of the troubadours today, Palomares comments that:

The [younger] generations have been undergoing a process of depoliticization. There is a huge number of troubadours in Mexico... highly influenced by Silvio [Rodríguez] and Pablo [Milanés], also by [Luis Eduardo] Aute, [Joaquín] Sabina, etc. The [Mexican] nueva trova movement is apolitical and out of context. The songwriters have appropriated the beautiful, poetical, and musical parts of Silvio [Rodríguez], but they do not know how to interpret the political part. ${ }^{32}$

Canto Nuevo was initially disseminated, in the 1960 and 1970s, in venues known as peñas. Descended from the traditional European café, these locations brought together musicians, artists, and writers with similar political inclinations. One of the most important was Chez Negro, owned by Salvador "Negro" Ojeda, a founding member of the group Los Folkloristas and one of the pioneers of Canto Nuevo's historiography. The group Los Folkloristas was formed in this space and later opened their own club with the same name at Calle de Manzanas \#64 in Colonia del Valle, with the objective of teaching Latin American folklore classes and presenting national and international artists. Among the most relevant songwriters who performed there were Víctor Jara, Silvio Rodríguez, Amparo Ochoa, and Gabino Palomares. Ojeda explains the following about the origin of Los Folkloristas:

\footnotetext{
${ }^{30}$ See Peter Bürger, Theory of the Avant-Garde (Minneapolis: University of Minnesota Press, 1984): 22.

31 Tanius Karam, "Notas para pensar la Nueva Canción mexicana: De Los Folkloristas a Alejandro Filio,” 33.

32 Cited in Farid Álvarez, "Entrevista a Gabino Palomares," in Latinoamericano Revista Digital, 25 (April 2014), http://latinoamericanorevista.org/2014/04/25/entrevista-a-gabino-palomares.
} 
With respect to folklore, some of us "carried it within" since the founding of Chez Negro, because it was part of the culture we inherited from our regions of origin. Other members of the group came into contact with Latin American folklore from other countries during their travels, and still others, especially the scholars who came from Paris, had already gotten a start in folklore through the dissemination of this genre that emerged in that city. From the conjunction of these experiences, the pioneering group called Los Folkloristas was born. ${ }^{33}$

The restaurant and music club El Mesón de la Guitarra, founded by Fernando Irabién, was the first venue where Palomares performed when he arrived in Mexico City in 1976. There he met Amparo Ochoa, a central figure in the Mexican popular music scene, and in a certain way became her protégé. Ochoa allowed him to sing his own songs during her presentations. Later, she interpreted and recorded some of Palomares's most iconic songs, including "La maldición de Malinche" (Malinche's Curse, 1978) and “¿Quién tiene la voz?” (Who owns the voice?, 1983).

Other important peñas of that period, which served as vital spaces for the emergence of Canto Nuevo, were El Cóndor Pasa and Peña Tecuicanime. Located at Rafael Checa \#1 in the San Ángel neighborhood, El Cóndor Pasa was inaugurated on July 8, 1972, by Ángel Cervantes. This venue was slightly more commercial than the others, offering a less politically-engaged repertoire in which romantic songs and watered-down Andean music were often performed. Nevertheless, it in fact contributed to the promotion of folk music and consequently of Canto Nuevo. ${ }^{34}$

Peña Tecuicanime was located at Tonalá Street \#99 in Colonia Roma. Mexican Anthar López and Chilean Margarita Cruz, both singers, founded it. This peña became a valuable hub for socially-engaged music, showcasing artists such as Óscar Chávez, Los Calchakis, Soledad Bravo, Amparo Ochoa, and Alfredo Zitarrosa, among many others. Palomares first performed there in 1976. It was during this year that the songwriter began his participation in the Mexican Communist Party (PCM), joining Valentín Campa's campaign, an important step in his social and political education.

Two record labels were instrumental in the production and dissemination of Canto Nuevo: Discos Pueblo, founded by José Ávila in 1973, and Ediciones Pentagrama, founded by Argentinian Modesto López in $1981 .^{35}$ The mission of these companies was to create a sonic space for cultural resistance in the face of the hegemony of corrupt and powerful corporations such as Televisa and Mexican commercial radio. $^{36}$ They contributed to the formation of a new educated audience, maintaining a line of musical and lyrical quality without making concessions to fashion or economic interests. By recording and promoting artists such as Ochoa, Chávez, and Palomares, these labels helped Canto Nuevo singers spread an alternative historical national narrative, which is essential to understand Mexico's cultural heritage.

In 1982, Palomares made a similar observation:

Our music is dismissed by transnational companies. This phenomenon is understandable, as our themes are in direct conflict with their interests. Fortunately, there are recording

\footnotetext{
${ }^{33}$ Salvador Ojeda, "Panorama del Canto Nuevo en México," 25.

${ }^{34}$ Palomares also sang regularly in El Nahual, a peña founded by Nacho Jiménez, in Coyoacán.

${ }^{35}$ Other important record labels that contributed to the development of non-commercial music in Mexico were Cultura Latinoamericana, Discos Fotón, Opción Sónica, Alerce, Cora-son, Discos Denver, Alacrán Producciones, and Alebrije. On these companies, see Jorge H. Velasco, El canto de la tribu, 174-177. On Nueva Canción and its relationship with the mass media in Chile, Argentina, Cuba, and the United States, see the excellent study by Jane Tumas-Serna, "The Nueva Canción Movement and Its Mass-Mediated Performance Context," in Latin American Music Review 13, no. 2 (1992): 139-157.

${ }^{36}$ To gain access to the airwaves in Mexico, artists and record labels needed to pay the so-called payola, money or gifts to be given to broadcasters or programmers in order to be played. Failure to do so often meant a total ban from the airwaves. For a good explanation of this phenomenon, see the commentary by Jorge Alvarez, former artistic director of Capitol Records in Mexico, in Reyes Matta, "The New Song and Its Confrontation in Latin America," 454-455.
} 
companies that, though small, allow us to record. Our work recalls that which the minstrels did in their time. There is a lack of truthfulness in the communications media, and we fill the gap. It is arduous work, above all because we do not have the materials necessary, but the people's acceptance of our work is what leads us to go forward. ${ }^{37}$

\section{Gabino Palomares: A History of Canto Nuevo}

From 1977 on, Palomares began to establish himself, alongside Amparo Ochoa and Óscar Chávez, as one of the central figures of the Canto Nuevo movement. On April 23 and 24, he participated in the First Festival of Opposition in the National Auditorium. The same year, he performed in the Palacio de Bellas Artes alongside Los Folkloristas, Amparo Ochoa, and the group La Nopalera. He also participated in a series of concerts in the Polyforum Cultural Siqueiros next to Amparo Ochoa and the group Sanampay. On August 16, he sang with Los Folkloristas, Amparo Ochoa, and Chava Flores in the First Festival of the Mexican Workers' Party (PMT). At the end of the year, he participated alongside Óscar Chávez and Amparo Ochoa in the Second Festival of the PMT in the Arena Coliseo in Mexico City. It was then that the Canto Nuevo movement was established as a cultural and political force, with a clear intention of challenging the official propagandistic discourse of the PRI, which was disseminated through Televisa, the hegemonic multimedia company founded by Emilio Azcárraga Vidaurreta.

In 1978, Discos Pueblo released Palomares's first recording, the album La maldición de Malinche (Malinche's Curse). It counted on participation by Grupo Canek, Ramón Sánchez, Gerardo Tamez, Armando Vega, and José Ávila, all influential musicians in the history of the movement and whose arrangements, a mixture of avant-garde and folkloric styles, make this album one of the most significant and achieving documents not only for Mexican Canto Nuevo, but also of the international Nueva Canción movement. The album cover art included engravings by Mexican artist Leopoldo Méndez (19021969). The album also included praise from Los Folkloristas, which reads:

These songs talk about Mexico, a Mexico that hurts at seeing the immense disparity between millions of poor and a few thousands in power. These songs are new because we didn't use to sing like this in Mexico. These songs sing with the voices taken from so many Mexicans who still don't know why they are poor. They sing with a voice full of old rebellions and new hope. These songs don't sing blindfolded, they sing without a gag on their consciousness. This is Mexican Canto Nuevo. ${ }^{38}$

All songs on the album are written by Palomares. The album includes the titles "Mi desierto" (My Desert), "Nicaragua", "La letanía de los poderosos" (The Litany of the Powerful), "Son del obrero" (The Worker's Son), "La maldición de Malinche" (Malinche's Curse), "Canto por la raza” (A Song for My Race), "La boa, las rosas y las espinas" (The Snake, the Roses and the Thorns), "Canto de amor" (Love Song), and "A la patria" (To the Motherland). These songs served to establish Palomares as one of the most respected writers of the Mexican protest song.

According to musicologist Jan Fairley, the song "La maldición de Malinche" is "surely one of the

${ }^{37}$ Cited in Roger Wallis and Krister Malm, Big Sounds from Small Peoples: The Music Industry in Small Countries (New York: Pendragon Press, 1984): 153.

38 "Este canto habla de México. Del México que nos duele por tanta desmesura entre millones de pobres y unos cuantos miles de poderosos. Este canto es Nuevo porque antes no se cantaba así en nuestro país. Canta con las voces que tomó de tantos mexicanos que aún no saben por qué son pobres. Canta con voz nueva en esperanzas y vieja en rebeldía. Canta sin venda en los ojos ni mordaza en la conciencia. Este es Nuevo Canto mexicano.” Back cover of the album La maldición de Malinche. 
most important songs of the Americas." 39 The song has often been labeled as such because it constructs a postcolonial discourse that denounces European and mestizo exploitation of Latin American indigenous peoples. The critic Mike Gonzalez defines it as "a moving and brutal attack on imperialism and a poignant illustration of the violated innocence of Latin America." 40 The harmonic simplicity of the song, based on only two chords ( $\mathrm{I}$ and V)-a typical construction in Mexican corridos (a popular genre dating back to the eighteenth century) - led to an anecdotal comment by an audience member at the Second Workshop of Latin American Popular Music in Rosario, Argentina in 1984. The unidentified spectator described the song as "the history of Latin America in the tonic and dominant."

Addressing conquest and colonization, the song chiefly exposes the consequences of racism in one of its most common and damaging expressions: malichismo, that is the rejection of one's birth culture and people, and preference and admiration for what is foreign. ${ }^{42}$ In the famous final lines of the song, Palomares wrote:

Today, in the twentieth century blond people keep coming to us and we open our homes to them and we call them friends.

But if there arrives an Indian, walking from the mountain, we humiliate him and see him as a stranger in his own land.

You, hypocrite, you who appear humble

before the stranger

but become arrogant

with your brothers.

Oh, Malinche's curse, sickness of the present, when will you leave my land?

When will you make my people free? ${ }^{43}$

The content of "La maldicion de Malinche" stands alone in the Mexican song tradition and remains to this day one of few musical works to address the blatant physical and symbolic discrimination against the continent's indigenous peoples by their mestizo counterparts. The song has been translated into several languages and is a frequent academic reading in university courses worldwide. "La maldición de

\footnotetext{
39 Jan Fairley, "Alive and Performing in Latin America: Review," 109. https://doi.org/10.1017/S0261143000002609. 40 Mike Gonzalez, "April in Managua: The Central American Peace Concert Popular Music," in Popular Music 6, no. 2 (May 1987): 248. https://doi.org/10.1017/S0261143000006061.

${ }^{41}$ There is no written record of this story, as is often the case in the historiography of Canto Nuevo. The story has been told over and over again and so has become part of the movement's oral tradition.

42 The term malinchismo refers to La Malinche, an indigenous (Nahua) woman offered as a slave to Spanish conquistador Hernán Cortés. She served as interpreter and cultural translator, facilitating —in some modest way- the conquest of Tenochtitlan. In Mexican imagination, the figure of La Malinche embodies betrayal. For a historical account of the La Malinche myth, see Sandra Messinger Cypess, La Malinche in Mexican Literature from History to Myth (Austin: University of Texas Press, 1991).

43 "Hoy en pleno siglo veinte / nos siguen llegando rubios / y les abrimos la casa / y los llamamos amigos. / Pero si llega cansado / un indio de andar la sierra / lo humillamos y lo vemos / como extraño por su tierra. / Tú hipócrita que te muestras / humilde ante el extranjero / pero te vuelves soberbio / con tus hermanos del pueblo. / Oh, maldición de Malinche / enfermedad del presente / ¿cuándo dejarás mi tierra? / ¿cuándo harás libre a mi gente?”
} 
Malinche" has transcended the limits of its generation, surviving the collapse of the ideologies and aesthetics of the Cold War, to become an essential part of twentieth century Hispano-American culture and musical memory. It is Palomares's best-known song both in Mexico and abroad. ${ }^{44}$

The song "A la patria" is a call to revolt and a criticism of uninformed and passive people who are subjected to the vexations of a repressive and manipulative state power. In Palomares's works, the customary revolutionary lexicon inherited from the Argentinean Nuevo Cancionero, the Chilean Nueva Canción, and the Cuban Nueva Trova appear. Words such as motherland (patria), struggle, rage, strategy, awareness, and freedom pervade the verses, calling for suffering to be turned into a weapon against the powerful. This is well reflected, again, in the last lines of the song, in which Palomares wrote revolutionary stanzas rarely seen in the Mexican lyrical landscape of the 1970s:

Let rage turn into fight, brother, defending what your hands produced.

The wealthy are not worth anything without your hours, which are shared with the vultures of the state.

We will respond to lies, rage turned into strategy, pain into an organized maneuver and this fight from below into a consciousness.

I will only call you my homeland

if we take over the reins and the way.

I will only call you a free country

if the wealthy do not mark your destiny. ${ }^{45}$

The song "La letanía de los poderosos" shares with "A la patria" a call to uprising, but this time through an original and strategic narrative device: the text speaks to the oppressed from the perspective of power. The poetic voice of the song is that of a poderoso (a powerful one), a land/factory owner or governor. The song exposes the reactionary discourse that seeks to blame poor and disenfranchised people for their own misery. It draws irony to the legitimization of violence by a paternalist government that tries to convince its citizens that it is better to be happy with little or nothing than to fight for better living conditions. "You have a quiet town. / Why do you complain, poor worker. / If your wage is not enough / it's very simple: work more!" 46 The consequences of not being satisfied with one's misery, the song shows, are violence and repression. Palomares depicts a corrupt society in which the church, the police, the army, the newspapers, the ruling class, and the judges all defend the interests of a sinister economic elite: los poderosos (the powerful). "Soldiers defend me / because I paid their wages. / My money buys laws, / governors and judges here." ${ }^{47}$ The song ends with an ironic stanza in which the poetic voice mocks the official ideals of peace and prosperity promoted by the Mexican government and makes clear that money will allow the powerful to force his rule over those-the workers, the people-whom he considers weak

\footnotetext{
${ }^{44}$ For an analysis of the song, see Janet Sturman, The Course of Mexican Music (New York: Routledge, 2016): 233-238.

45 "Que la rabia se torne en lucha hermano / defendiendo lo que hicieron tus manos / nada valen los ricos sin tus horas / que comparten a los buitres del estado. / Responderemos ante la mentira / la rabia convertida en estrategia, / el dolor en maniobra organizada / y esta lucha de abajo hecha conciencia. / Solo habré de llamarte patria mía / si tomamos las riendas y el camino / solo habré de llamarte patria libre / si los ricos no marcan tu destino.”

46 "Tienes un pueblo tranquilo / ¿de qué te quejas obrero pobre? / Si el salario no te alcanza / todo es muy fácil, trabaja doble."

47 "Los soldados me defienden / porque su sueldo lo pago yo. / Mi dinero compra leyes / gobernadores, jueces de aquí."
} 
and naïve: "Long live love and peace. / Long live our institutions. / I will reign with my money / in this country of cowards." 48

Renowned composer Gerardo Tamez arranged the song, appropriately capturing the reproachful tone of the powerful through a rhythmic leitmotiv that the percussion instruments repeat incisively at the beginning of each section. The mastery of the arrangement for guitar, string quartet, percussion, and flute also perfectly translates the dramatic tension of the text into music. The album includes other outstanding arrangements by Tamez and Avila, which made it one of the most accomplished recordings of the protest song repertoire in Mexico.

All of the songs on the album revolve around the grand narrative of exploitation and revolt that characterized the discourse of the Nueva Canción. Only "Canto de amor" (Love Song) is concerned with romantic endeavors, but heir to a revolutionary sentimental education, love here is maintained within the realm of politics. It consists of social love, not between lovers, but between comrades, a love in the service of rebellion, characteristic of love narratives in protest songs. "With your green gaze in mine / Help me look at the future. / With your mouth on mine, comrade / Help me create a new life." ${ }^{49}$

Also in 1978, Gabino Palomares participated as an actor, singer, and composer in Felipe Santander's play El extensionista (The Extensionist), which premiered on November 6 in the Teatro de la Juventud in Mexico City. ${ }^{50}$ Palomares performed in the first hundred presentations of the play, yet El extensionista remained on the bill for over thirty years, a record in the history of non-commercial theater in Mexico. ${ }^{51}$ El extensionista tells the story of Cruz, an agronomist who goes to work in the indigenous community of Tenochtlén and is confronted with the terrible reality of its inhabitants, who live in the midst of corruption, poverty, ignorance, and repression from the caciques. The musical material from the play was compiled years later in Palomares's fourth album El extensionista (1985), edited by Discos Plan Joven. The songs on this album were mostly written by Santander and interpreted by Palomares. He nonetheless contributed three songs: "No te fíes de las palabras" (Don't Trust Words), "Dos sentimientos" (Two Feelings), and "Canción de amor" (Love Song), also included on the album Hace como un año (1984). The song stands out for its poetic play and for the force with which it enacts the scene where Cruz and Manuela, the daughter of the peasant leader, who is murdered at the end of the play, make love for the first time.

Other important events in 1978 include Palomares's concert with Silvio Rodríguez and Noel Nicola at the Polyforum Cultural Siqueiros in Mexico City and his participation in the 11th World Festival of the Youth and Students in Havana, Cuba. The Mexican delegation to this event included Palomares, Los Folkloristas, Grupo Víctor Jara and Amparo Ochoa.

In Palomares's second album Fabricando la luz (1980) (Manufacturing the Light), the lyrics oscillate between the grand socio-political narratives of the Cold War and the intimate narratives of love. Three songs on the album cover political and social themes: "El Salvador, continuamos" (El Salvador, We Keep Going), which addresses the Civil War in El Salvador; "Cipriano Hernández Martínez," a song by Mexican singer songwriter and painter León Chávez Texeiro, which recounts the killing of a worker who rebels against his boss; and "La mujer (se va la vida compañera)" (Woman: Life Passes By, Comrade), also by

48 "Viva el amor y la paz / vivan las instituciones. / Reinaré con mi dinero / en este pueblo sin pantalones."

49 "Con tu verde mirada en mi mirada / ayúdame a mirar hacia el mañana. / Con tu boca en mi boca, camarada / ayúdame a lograr la vida nueva."

${ }^{50}$ An extenisonista in Mexico is a salaried worker who promotes and manages rural and agricultural developments.

${ }^{51}$ Donald H. Frischmann, "Desarrollo y florecimiento del teatro mexicano: siglo XX," in Teatro: revista de estudios teatrales 2 (1992): 57, http://hdl.handle.net/10017/4457. 
León Chávez Texeiro, which denounces the tediously repetitive and exhausting days of a woman from the working class who tries to move on with dignity, but whose life, as the chorus states, "goes down the hole, like dirt in the laundry room."

"El Salvador, continuamos" (El Salvador, We Keep Going) is one of the Nueva Canción songs that most movingly poeticizes the terrible yet promising experience of the Salvadoran Civil War. The song emerged from Palomares's participation, alongside members of the then Socialist Current and the Workers' Revolutionary Party, in the creation of the Mexican Committee in Solidarity with the Salvadoran People (1979). The committee later became one of the main international supports for the Farabundo Martí National Liberation Front (FMLN). It was part of the committee's work to organize numerous festivals in support of El Salvador, including the First Festival in Solidarity with the Salvadoran People on December 13, 1980. Several artists participated in this festival, including Alfredo Zitarrosa, Amparo Ochoa, Los Folkloristas, and Gabino Palomares himself. He also acted as organizer alongside Epigmenio Ibarra, an important Mexican filmmaker and war correspondent. On December 20, 1980, the Unified Popular Action Front (FAPU), a Salvadoran guerrilla organization, organized a series of popular concerts in El Salvador. On this tour, Palomares witnessed clashes between the army and the guerillas, in some cases during his concerts, to the extent that the tour had to be suspended due to safety concerns. ${ }^{52}$ These experiences helped Palomares to craft the beautiful poetic images in the song masterfully.

This country beautifully painted

with the people's voice on the walls

marching with courage through the streets

defining its things and its people.

America's waist catches fire

and the flame spreads from people to people.

What is it about these murdered men

that they are reborn multiplied in the sun?

The little brother grows gigantic,

becoming a thousand-headed hurricane

maturing and fighting he rises,

with his peculiar voice has said enough.

[...] Light will shine through this blood, sister

the future will come by force through shrapnel.

There is nothing else to do, working hands.

Salvadoran, snatch your history! $!^{53}$

Four songs on the album are dedicated to intimate, loving themes: "Este es un día" (This is a Day), "Cabalgando" (Galloping), "Fabricando la luz" (Manufacturing the Light), and "Canción triste" (Sad

\footnotetext{
${ }^{52}$ During this tour, a dissident group formed the Revolutionary Democratic Front (FDR), which included several congressional representatives, mayors, a former judge from the Supreme Electoral Tribunal, as well representatives from several guerrilla groups. This was, in essence, a declaration of war against the government. See David Hernández, "Nace el Frente Democrático Revolucionario,” in La Opinión (July 16, 2005): 7A.

53 "Este país bellamente pintado / con las voces del pueblo en las paredes. / Por la calle con fe marcha valiente / definiendo sus cosas y la gente. / La cintura de América se incendia / y la llama se esparce pueblo a pueblo/ ¿Qué tienen estos hombres asesinados / que renacen al sol multiplicados? / El hermano pequeño se agiganta / Se vuelve un huracán de mil cabezas / Madurando y luchando se levanta. / Con su voz peculiar ha dicho basta. / Vendrá la luz por esta sangre, hermana. / Vendrá el futuro a golpes de metralla. / No hay más que hacer, manos trabajadoras. / Salvadoreño, arrebata la historia.”
} 
Song). These four songs deal with love issues, both at the family level-the love of a father toward his son-and the breakup of a love affair. In all of them we can see how the Canto Nuevo's revolutionary and progressive approach to love opposes the traditionally male chauvinistic discourse in popular music and in the music promoted - then and now—by multinational corporations. On this, Palomares has explained how mainstream love songs "cling to themes of egocentric love between men and women, and it's superficial at best. [...] New Song artists, on the other hand, strive to be the messengers of the most elemental aspirations of humanity." ${ }^{24}$ That is not to say that machismo and superficiality are not present in Canto Nuevo texts; they are. But most of the songwriters of the movement, and Gabino Palomares above all, present a distinct and refreshing kind of sensibility, especially for a country educated emotionally by corridos, boleros, and telenovelas. The great folk musician, painter, and ethnomusicologist René Villanueva rightly commented on this in his appraisal of Palomares's third album Hace como un año (“About a Year Ago"):

Love, the greatest song theme of all times, has its deepest and most questioning expression in the Nueva Canción, for it reveals to what extent a love relationship is also part of and reproduces systems of domination and servitude. And thus, when fighting to change these old structures of social exploitation, the result will consequently be a freer love relationship, more fully and deeply humane, where the fight against older models of the appropriation of beings, domination, and servitude must take place every day. And in love, as in everything else, this is a daily and constant struggle, not against the beloved man or woman, but against the old molds of human relationships established by the old capitalist society. ${ }^{55}$

In the song "Fabricando la luz," for example, Palomares creates an allegory of love through light and shadow. The man, with light outside and shadow within, gives his light to a woman; the woman, with light within and shadow without, does not give the man light but teaches him to make his own. In the song, the lovers complement each other, illuminate each other, and then they separate: the man illuminated within the woman, the woman still trying to produce her outside light, a metaphor for the challenges the women's movement faced in the 1980s in Mexico. "Fabricando la luz" is a call for a woman's independence and an invitation for her to manufacture her own light, with the help of but independently from a man. Light is understood not as a synonym for love, but as a vital energy that can create something more than a selfish and traditional romance.

There comes a single man, accompanied

by light outside and shadow inside,

searching for a light for his shadow

and casting light from outside on the shadows.

There comes a woman with shadow outside, an immense light shining within, product of her daily struggle searching for a light for her shadow.

[...] But here resides the difference:

she did not give her inside light.

She taught him how to create it.

He created a light for his shadow.

\footnotetext{
${ }^{54}$ Alice Horrigan, "New Song: New Political Song?," in The Valley Advocate (July 28, 1986): 8.

${ }^{55}$ Back cover of Gabino Palomares, Hace como un año, Discos Pueblo, México, 1984, LP.
} 
[...] I cannot see you shadowed, comrade.

You will earn your light creating it.

And by joining our lights in flame,

we will be dangerous comrades. ${ }^{56}$

The remaining two songs on the album, "El piojito" (The Little Louse) and "El moco" (The Booger), are not political, nor do they deal with loving relationships: both are popular songs by unknown authors, which Palomares used to legitimize humor and absurdity as strategies of resistance, and to make clear the important influence of popular music on Canto Nuevo. Humor is a recurrent visitor in Palomares's work, for it represents an essential element of human experience in adverse situations. This perhaps explains why humor has been so important for Palomares and why, throughout his career, he has gone back, over and over again, to perform the works of one of Mexican popular music's main composers: Salvador "Chava" Flores. Palomares and Flores share an interest in everyday life, especially in the working classes, always through a critical filter that leads to reflection. From the beginning of his career, Palomares included Flores's songs as part of his repertoire, making them known not only in Mexico but also abroad. For Salvador Ojeda, one of the triumphs of Canto Nuevo was to have "rescued Salvador 'Chava' Flores from the commercial stream, where it has been always underestimated, a great composer who represents the most authentic strain of urban folklore." ${ }^{27}$ Part of Flores's work, interpreted by Palomares, was compiled on the record Gabino Palomares interpreta a Chava Flores, published in 2010, by Discos Pentagrama.

From 1981 to 1984, Palomares's musical career continued to rise. On February 13, 1981, he participated in the festival Solidarity with the Peoples of Central America at the National Autonomous University of Mexico (UNAM). In November of that same year, he went on a twenty-concert tour to universities in the United States, also in solidarity with El Salvador.

On April 4, 1982, he appeared in the above-mentioned First Festival of Latin American Canto Nuevo at the National Auditorium and in May he traveled to Quito, Ecuador, to participate in the Latin American Songwriters Conference: Luis Alberto Valencia. On November 27, the Festival for the Tenth Anniversary of Cuban Nueva Trova was held in Varadero, Cuba. At this festival, the Nueva Canción movement's Permanent Committee was created on Pablo Milanés's initiative. The committee consisted of Daniel Viglietti (Uruguay), Armando Tejada Gómez (Argentina), Carlos Mejía Godoy (Nicaragua), Chico Buarque (Brazil), Pete Seeger (United States), Óscar Chávez (Mexico), Silvio Rodríguez (Cuba), Joan Manuel Serrat (Spain), and Angel Parra (Chile). All agreed to elect Gabino Palomares (Mexico) as Secretary General of the committee, a position he held until 1988. The main objectives of the committee included creating national committees and organizing international festivals of Nueva Canción all over the continent, as well as providing assistance to singers who were victims of persecution, imprisonment, and exile. There was no term limit for the committee; its activities simply decreased over time until it completely disappeared in 1988.

In December 1982, Palomares performed at the PSUM '82 Festival in Mexico City's Sports Palace,

\footnotetext{
56 “Ahí viene un hombre solo, acompañado / con una luz afuera y sombra adentro / buscándose una luz para su sombra / y dando luz de afuera a las sombras. / Ahí viene una mujer con sombra afuera / con una inmensa luz brillando adentro / producto de la lucha cotidiana / buscándose una luz para su sombra. [...] Pero de aquí nació la diferencia. / Ella no regaló la luz de adentro. / Le enseñó a fabricarla al compañero. / Él fabricó una luz para su sombra. [...] No te puedo ver sombra, compañera. / Te ganarás la luz al fabricarla. / Y uniendo nuestra luz en llamarada / Seremos peligrosos camaradas.”

${ }^{57}$ Salvador Ojeda, "Panorama del Canto Nuevo en México," 28.
} 
and from April 24-30, 1983, he traveled to Managua, Nicaragua, where he participated in the Second Nueva Canción Forum Festival, an event that became known as April in Managua. At this important festival, Palomares appeared alongside great figures of the international Nueva Canción such as Amparo Ochoa, the brothers Carlos and Luis Enrique Mejía Godoy, Silvio Rodríguez, Daniel Viglietti, Alí Primera, Mercedes Sosa, Adrián Goizueta, and Chico Buarque. Immediately afterward, Palomares returned to Mexico to perform a concert at the Second Festival of Latin American Canto Nuevo, alongside Amparo Ochoa, Julio Solórzano, Tania Libertad, Guadalupe Pineda, Carlos Díaz “Caito,” Marcial Alejandro, Isabel Parra, and Pedro Luis Ferrer, among others. Finally, in July 1983, he traveled to Caracas, Venezuela, where he participated in the Song Festival, organized by Alí Primera and Rafael Zalazar.

During this period, Palomares's career also expanded to Europe. In February 1984, he traveled to the German Democratic Republic, where he performed at the Festival of Political Songs alongside Óscar Chávez, Vicente Feliú, Yolacamba Ita, and Mario Montenegro. On his return to the American continent, he performed in Quito, Ecuador, at the Third Latin American Nueva Canción Conference. Then, on July 22, he traveled to Santiago, Chile, where he was to give two concerts-on July 23 and 24-that were never held. These had been organized by the record company Alerce, but upon his arrival in Chile, Palomares was detained. This was Pinochet's Chile, and when they learned who he was, he was immediately deported to Argentina. There he was received and welcomed by Mercedes Sosa before performing at the Second Popular Music Workshop in Rosario, Argentina.

In 1984, Discos Pueblo released Palomares's third LP, Hace como un año. Here, again, Palomares juxtaposes political and social themes with love songs, maintaining a very thin border between them. On the back cover of the album, René Villanueva commented:

Gabino Palomares is one of the most representative Mexican composers in Nueva Canción. The popular appeal he enjoys may be explained by his deep and daily connection with the people, their struggles and problems of a social nature, and also the attempt to question and overcome their internal battles in their most intimate and personal manifestation: the love relationship.

"Si pudiera" is one of these internal battles, a reflection on the breakup of love through a critical filter, which breaks with the traditional narratives of love promoted by mainstream media and the Mexican cultural industry. The first strophe of the song establishes a nostalgic aura, which is enhanced by a beautiful musical arrangement for strings and brass by José Ávila. As the song progresses, much as Octavio Paz does in his "Piedra de sol," Palomares figuratively describes the lover's body as the earth, creating metaphors in which love and indifference play with each other in a liminal space, half earth and half woman.

If I were to go crazy walking your beaches

and interpret your body

as the sun's score

If I were to make you out of straw

and unleash the fire

If I burn your vessels

The world belongs to us two. ${ }^{58}$

In “¿Quién tiene la voz?” (Who Owns the Voice?)—a song masterfully performed by Amparo

58 "Si me volviera loco recorriendo tus playas / Y tomara tu cuerpo partitura del sol / Si te hiciera de paja / Y le doy rienda al fuego / Si te quemo las naves / El mundo es de los dos." 
Ochoa in her album Vamos Juntos (1986) - Palomares talks about the power of affirmation and hope through the voice of the people. "The song," a recurring character in Nueva Canción narratives, is in this case an allegory for the expression of subjugated people. The similarity between song and life was a fundamental poetic resource of the movement, and Palomares's stanzas here suggest the potential of language to build a common bridge to the future. The song is a call for the assertion of the collective and individual voices. Yet Palomares makes it clear that freedom cannot be given; it must be achieved and articulated either by oneself or by the people working as a single sonic entity.

With this voice the thousands of rages

that fill my throat

with the song, a feeling

turned into a dove rising in flight.

This song scares off fear

And an explosion of discontent

becomes a torch, sun, and wind

forgets time and challenges the heavens.

[...] There will be song as long as people

do not resign themselves to chains

There will be hope as the strings

Are able to sound full of love

Who owns the voice after all?

Who should be the one to change your sadness?

Who will mark your own path for you?

Who, if not you, has the answer? ${ }^{59}$

The title song of the album, "Hace como un año" (About a Year Ago)—with music by Daniel Tuchman - is the story of a truncated love. Here the poetic voice illustrates the trajectory of love, a year after the breakup, through a recurrent temporal motif. The song constructs an emotional spiral sustained in memory, which becomes deeper verse after verse. The danger of forgetting what time has nurtured is combined with a strong desire to remember a brief infatuation.

The remaining titles on the album—all written by Palomares—are mostly love songs with a political bent: "Canción de amor" (Love Song), from the play La extensionista; "Laura," a love song to a former guerilla lover; "Quisiera” (I Want); “2 de septiembre” (September 2); and “¿Buenos días?” (“Good Morning"). The only cover on the LP is "Bella fugitiva" (Beautiful Fugitive), an accomplished composition by L. E. Lizardi, with music by Daniel Tuchman.

The literary quality of the three albums released to that date (La maldición de Malinche (1978), Fabricando la luz (1982) and Hace como un año (1984)) constitute one of the most coherent examples of political song in Mexico, and in and of themselves confirm Palomares as one of the most original and accomplished lyricists of the Canto Nuevo.

In January 1985, Palomares performed at the Nueva Canción Festival in Lima, Peru, on the 450th

\footnotetext{
59 “Con esta voz miles de rabias / que me alborotan la garganta / con la canción un sentimiento / vuelto paloma alzando el vuelo. / Esta canción espanta el miedo / Y una explosión de descontento / Se vuelve antorcha, sol y viento / Olvida el tiempo y reta al cielo. / [...] Habrá canción mientras un pueblo / no se resigne a las cadenas, / habrá esperanza mientras puedan / llenas de amor sonar las cuerdas. / ¿Quién tiene la voz después de todo? / ¿Quién ha de cambiarte la tristeza? / ¿Quién te marcará tu propia senda? / ¿Quién, si no eres tú, da la respuesta?”
} 
anniversary of the city's founding. On September 19 of that same year, an earthquake occurred in Mexico City, and an outpouring of intense cultural activity ensued as an immediate response, in the form of festivals both in Mexico and abroad. Palomares participated in these festivals, raising funds and food for the victims. From this experience, he wrote the song "La tierra nos ha puesto a prueba" (Earth has Tested Us), recorded on the album México a través de su canto (2010). Here, Palomares chronicles the moments and emotions caused by the earthquake, with verses such as:

The postcard changes in three minutes

All that remains is man for man

The great fragility is revealed to us

Because the earth has tested us.

The uncontrolled rush came to a sudden stop

All miseries were laid bare

The doves, the blasphemies flew

Because the earth has tested us. ${ }^{60}$

In April of 1986, Palomares participated in Peace on Earth Begins in Central America in San José, Costa Rica, and soon afterward began a tour through the United States where he performed at the University of Illinois's Latino Festival. While on this tour, Palomares sang at Yale University alongside Pete Seeger, the seminal American songwriter and pillar of the American protest song. This concert also served as a forum for discussion about the future of the Nueva Canción through work by the movement's Permanent International Committee and the Committee on New American Song, founded by Seeger, Nilda Morales, and Gisele Mills. After the concert, both minstrels were hailed as "heavyweights" of the International New Song movement. ${ }^{61}$ On Palomares, one reviewer noted: "With a life committed to political change, Gabino Palomares is a major force behind the international New Song Movement." ${ }^{2}$ According to Jorge Velasco:

The song, with a clear and direct political connotation, has a notable representative in the figure of Gabino Palomares, who like many other composers of this movement is aware that his literary work offers a different option for a public saturated by fashionable songs and commercial successes imposed by the media and the entertainment industry. ${ }^{63}$

While Velasco's comment is accurate, Palomares's precious coherence changed in 1987, when he recorded for the first time with a multinational company, BMG Ariola. BMG produced the albums No te creo nada (I Don't Believe You) (1987) and ¿Qué vamos a hacer? (What Are We Going to Do?) (1989). In both productions, the intrusion of corporate ideology is palpable. Preoccupied with sales, the artist's integrity is threatened, regardless of musical genre and including protest songs. The cover of No te creo nada, in which Palomares appears in a tuxedo, smiling like a crooner, plays a significant semantic game between the visuals and the customary left wing, revolutionary rhetoric that characterizes Palomares's work. Even though the cover pretends to be humorous, it evidences the unabashed, profit-oriented intentions that a corporation such as BMG had for Canto Nuevo.

Moreover, the album includes a disproportionate number of covers: "Érase una vez en Hollywood"

\footnotetext{
60 "Se cambia la postal en tres minutos / Y solo queda el hombre para el hombre / La gran fragilidad se nos revela / Porque la tierra nos ha puesto a prueba. / La prisa sin control paró de pronto / Se desnudaron todas las miserias / Volaron las palomas, las blasfemias / Porque la tierra nos ha puesto a prueba."

${ }^{61}$ Alice Horrigan, "New Song: New Political Song?," 8.

62 Ibid.

${ }^{63}$ Jorge H. Velasco, El canto de la tribu, 158.
} 
and "No te creo nada" by Cacho Duvanced; "Lucía" by Carmina Canavino; "Satisfaga sus deseos" by Roberto González; and "Capitan" by Marcial Alejandro. All of them, with the exception of "Capitán," reveal a failed attempt to make the political song accessible to a broader audience by bringing it dangerously close to the mainstream market. The musical arrangements by Alberto Nuñez, oriented toward the commercial sound of pop music, contributed to the aesthetic de-territorialization of this album. In "No te creo nada," an unfortunate rock-pop sound disappointingly evokes the musical productions of Televisa. The songs "Satisfaga sus deseos" and "Érase una vez en Hollywood" bring back the humorous content studied before, but no longer in the form of popular music from the people, as in Fabricando la luz, but rather as a more commercial form of humor.

Although many members of the Nueva Canción constantly resorted to pop sonorities, including Pablo Milanés, Joan Manuel Serrat, Luis Eduardo Aute, and others, Palomares had maintained a more selfgoverning path, opposed to the market aesthetics and obligations of big corporations. That path was somehow fractured in this album. Fortunately, the texts written by Palomares remained within the parameters of his previous works, in spite of the musical arrangements. For this LP, Palomares wrote "Quiero una canción" (I Want a Song); "Oh mi país (Oh, My Country); "Algo refrescante" (Something Refreshing), with music by Cacho Duvancet; and "Verso desconfiado" (Suspicious Verse). The album also included an orchestral version of "La maldición de Malinche."

On the album ¿Qué vamos a hacer? (1989), also with Ariola, Palomares wrote all of the songs but this time moved away from political content and concentrated instead on love songs that, although well crafted, belong more to the Trova Mexicana genre than Canto Nuevo. It was an understandable shift, motivated perhaps by the fall of the Berlin Wall. The LP included "Despedida" (Farewell), "Y si la mar..." (If the Sea...), "Tengo” (I Have), "Yo la quería” (I Wanted Her), “¿Qué vamos a hacer?” (What are We Going to Do?), “Amo" (I Love), "Saber que existes" (Knowing That You Exist), "Te alejas” (You Distance Yourself), "Tal Vez" (Maybe), and "Ay la ciudad" (Oh, the City). Only the album's title track and "Ay la ciudad" save the production from total depoliticization and maintain Palomares within the political song genre. "¿Qué vamos a hacer?" denounces people’s indifference in the face of their own oppression, through stanzas which transcend their own time and remain valid even today:

There are still those who patiently wait

sitting comfortably in an armchair

for the corpses of fear

and the misery to pass

without paying the price

There are still those with a book in hand

Who ask for the conditions to fight

Who are always ready to criticize

and from the balconies watch the march. ${ }^{64}$

It is important to consider the production years for No te creo nada (1987) and ¿Qué vamos a hacer? (1989) within the global political context of the Cold War. One of the far-reaching consequences unleashed by the fall of the Berlin Wall in 1989, and the subsequent fall of the Soviet Union in 1991, was the ideological and ontological vacuum it left in the Latin American revolutionary left. This not only

\footnotetext{
64 "Hay todavía quien paciente espera / sentado en el sillón cómodamente / que pasen los cadáveres del miedo / y la miseria sin que nada cueste. / Hay todavía quien libro en la mano / pide para luchar las condiciones / y para criticar siempre está listo / viendo la marcha desde los balcones."
} 
profoundly affected Canto Nuevo and the international Nueva Canción, but eventually brought it to an end. Recording under BMG, Palomares is a perfect example of the global course taken by the protest song. This path increasingly focused on creating stars and individual careers in service of the market and not in service of a common revolutionary cause. Fortunately, after these two albums, Palomares radically changed course, avoiding commercial drift and returning to the space of resistance and marginality that constitutes his essence and the essence of Canto Nuevo.

In 1991, Palomares recorded the album Canciones contra la Guerra (Songs Against the War) in response to the United States' invasion of Iraq. This production by Discos Pentagrama brings back Palomares's engaging and thoughtful character. Although most of the songs on the album are reinterpretations of songs by other songwriters, including Fito Páez ("Yo vengo a ofrecer mi corazón"), León Gieco ("Sólo le pido a Diós”), Victor Heredia ("Sobreviviendo”), and Alí Primera ("No basta rezar"), among others, two songs, "Septiembre" and "Mercado Pérsico," both written by Palomares, stand out as examples of the Mexican protest song adapting to the new global geopolitical context. The album cover was a crafted version of José Sánchez Morado's drawing Bombardeo (Bombardment, 1938), made by the Mexican artist in opposition to Franco's atrocities during the Spanish Civil War. Although the central theme of the album is the Persian Gulf War, the songs go beyond this specificity, becoming part of a timeless and universal rejection of violence committed by states against civilian populations.

The last decade of the century marked the defeat of the many struggles that Canto Nuevo aimed to support. It was therefore a decade of adjustment and introspection in Palomares's work. This led to a long silence in Palomares's discography, broken only by the release of Historia cotidiana (Everyday Story) in the year 2000. The album is a remarkable literary achievement that contains thirteen original songs in which love, personal struggles, and social justice reappear with force, in ways not seen since his first three albums.

The first song makes reference to one of the key events of the decade, the uprising of the Zapatista National Liberation Army (EZLN) on January 1, 1994. The Zapatista uprising proposed new strategies of resistance and confirmed that neither the Cuban Revolution nor Soviet Communism were viable options for the times to come. Protest songs, however, were more necessary than ever. The Zapatista movement revived the ethos of Canto Nuevo and shook up a stagnant civil society that seemed to be more preoccupied with watching telenovelas than starting social revolutions. As homage to and in solidarity with the movement, Palomares composed one of his most transcendent works: "Espejos de mi alma" (Mirrors of My Soul). The song synthesizes the message that Palomares had been crafting for years in his work, the central idea of which is that Mexico cannot aspire to emerge from its underdeveloped state without accepting, once and for all, the inheritance, condition, wisdom, and beauty of indigenous peoples. "Indigenous peoples hold a mirror to our face," Palomares explains. ${ }^{65}$ "But sadly, this is a mirror that millions of Mexicans still refuse to see, and within the Mexican imagination, indigenous peoples continue to be seen as 'hired help' and blatant racism continues to be one of our greatest national failures." ${ }^{\circ 6}$ Along with "La maldición de Malinche," "Espejos de mi alma" stands as one of the most powerful and beautiful calls for justice and recognition of indigenous peoples ever written in the song tradition of the Spanishspeaking world.

Gone are the festivities of conquest, Five centuries of infamy and club,

${ }^{65}$ Cited in Jorge H. Velasco, El canto de la tribu, 159.

${ }^{66}$ Arturo Cruz Bárcenas, "Hoy, Gabino Palomares presentará su Historia cotidiana en la sala Ollin Yoliztli," La Fornada (March 22, 2001), http://www.jornada.unam.mx/2001/03/22/07anlesp.html. 
With the dawn bells of January

The trampled voices rise

Misery and pain was life here

Deceit and promises the answer given,

They grew doubtful whether I had a soul

And always forgot I existed

Glory to those who break the silence

Glory to the mirrors of my soul

Glory to those who shake their conscience

Glory to those who end their innocence. ${ }^{67}$

Another significant song on the album is "Indocumentado" (Undocumented), a Tex-Mex corrido with an outstanding accordion performance by Ramón Sanchez, one of the most talented multiinstrumentalist musicians of the Canto Nuevo, who accompanied Palomares and several other artists throughout their careers. Here, Palomares speaks about racism and the labor exploitation of Mexican and Central American migrants in the United States. It reiterates Palomares's long defense of the rights of undocumented workers, a struggle confirmed by the hundreds of concerts he has performed in the United States, particularly in California, Texas, and Illinois, and the widespread recognition of his work in Chicano and Mexican-American communities. ${ }^{68}$

The song "Hermosísimo lucero" (Most Beautiful Star), written by Palomares after the death of Amparo Ochoa in 1994, deserves special mention. The title of the song refers to one of the first songs performed by Ochoa in her native city of Culiacán. Palomares's relationship with Ochoa was one of the most touching within the movement, for their friendship never ceased to grow. "Hermosísimo lucero" is Palomares's tribute to both the public and private life of his beloved friend and artist, who taught him so much and encouraged him to keep writing and composing songs for the people. The last lines of the song are: "I do not accept the cruelty of your departure. / Is it because heaven was jealous of your singing? / I do not forgive life. I need you / Where are you, most beautiful star?"69

The remaining titles on the album are "Historia cotidiana" (Everyday Story), a poignant tale of the trap of romantic love and marriage as taught by patriarchal values; "Cantamos" (We Sing), a declaration of principles, a justification to sing for justice even decades after the end of the socialist utopia; "Reconstruirse" (Rebuilding Oneself), a tender call for putting oneself back together after failures and personal breakdowns; "Los Mochos" (The Sanctimonious), a flamenco rumba-something rare in Palomares-that mocks the conservative government of the National Action Party; "En el fondo del vaso" (At the Bottom of the Glass), an intimate reflection on alcoholism; "Uno a veces no tiene" (We Don't Always Have), a reflection on the father-son relationship; "Amor es bondad" (Love is Kindness), "El guardián” (The Guardian), and "Monseñor," are songs in which, for the first time, Palomares explores the

\footnotetext{
67 “Atrás quedó la fiesta de conquista / cinco siglos de infamias y garrote / con el alba de enero a campanadas / se levantan las voces pisoteadas. / Miserias y dolor fue aquí la vida / engaños y promesas la respuesta / llegaron a dudar si alma tenía / y siempre se olvidaron que existía. / Gloria a los que rompen el silencio / Gloria a los espejos de mi alma / Gloria a los que agitan la conciencia / Gloria a los que acaban la inocencia.”

${ }^{68}$ Part of Palomares's work as Secretary General of the Nueva Canción's International Permanent Committee consisted of bringing together Mexican artists and their compatriots living in the United States through the La Raza Festivals (19841986), a result of the collaboration between Palomares and Mexican-American actor, singer and composer Daniel Valdez. 69 "No me resigno a lo cruel de tu partida / será que el cielo tuvo celos de tu canto / no perdono a la vida y te requiero / ¿a dónde te hallas hermosísimo lucero?”
} 
idea of kindness from a spiritual perspective; and lastly, "No escapes" (Don't Escape), a beautiful love song.

Historia cotidiana is one of the best-crafted albums of the Mexican protest song. It remains one of the last_-and very late-examples of Canto Nuevo, a solitary vessel navigating a dark sea below a cluster of ephemeral stars whose egotistic glow will never bring light.

\section{Conclusion}

This closes our brief and schematic exploration of Palomares's work from 1978 to 2000. The veil that conceals the memory of Canto Nuevo affects almost all of the movement's songwriters and singers. So many stories are yet to be told. The absence of academic research on the movement is an important lacuna. This paper attempted to review Palomares's trajectory with the hope of encouraging new research on him and all of the other troubadours that stubbornly dedicated their life to singing to and for the disenfranchised. We must fold back the history of the spaces that became the movement's home-the peñas, bars, and cafes, the recording companies, committees, squares, universities, and unions-alongside the histories of the musicians - guitarists, pianists, bassists, percussionists, arrangers, and orchestratorswho for decades accompanied the songwriters and interpreters of the movement. There is also a need to examine the Mexican protest song phenomenon from the perspective of academic disciplines other than history, ethnomusicology, and music, such as postcolonial studies, gender studies, transatlantic studies, spatiality, popular culture, visual culture, linguistics, as well as literary and cultural studies. We need innovative and engaging approaches to understanding song lyrics, as well as original research into the social and spatial interactions of its protagonists both in Mexico and abroad. All these stories form an essential part of the cultural history of Mexico, and it is time for them to be written.

\section{Gabino Palomares's Discography ${ }^{70}$}

La maldición de Malinche, Discos Pueblo, México, 1978, LP.

Fabricando la luz, Discos Pueblo, México, 1980, LP.

Hace como un año, Discos Pueblo, México, 1984, LP.

El extensionista, Discos Plan Joven del CREA, México, 1985, LP.

No te creo nada, BMG Ariola, México, 1987, LP.

¿Qué vamos a hacer?, BMG Ariola, México, 1989, LP.

Septiembre: Canciones contra la guerra, Ediciones Pentagrama, México, 1991, LP.

Antología I, Discos Pueblo, México, 1997, LP.

Antología II, Ediciones Pentagrama, México, 1997, LP.

Historia cotidiana, Ediciones Pentagrama, México, 2000, LP.

Salimos, Ediciones Pentagrama, México, 2006, LP.

México a través de su canto, Ediciones Pentagrama, México, 2010, LP.

\footnotetext{
${ }^{70}$ Throughout his career, Palomares produced other albums, most of them including previously released songs. They do not appear here.
} 
Gabino Palomares interpreta a Chava Flores, Ediciones Pentagrama, México, 2010, LP.

\section{Bibliography}

Álvarez, Farid. “Entrevista a Gabino Palomares.” Latinoamericano Revista Digital 25 (April 2014), n.p.

Bernal, Julio. Se me reventó el barzón: Amparo Ochoa. Culiacán: Universidad Autónoma de Sinaloa, 1996.

Bürger, Peter. Theory of the Avant-Garde. Translated by Michael Shaw. Minneapolis: University of Minnesota Press, 1984.

Cabezas, Miguel. “The Chilean 'New Song.”' Index on Censorship 6, no. 4 (1977): 30-36. https://doi.org/10.1080/03064227708532673.

Cruz Bárcenas, Arturo. “Celebra Gabino Palomares 35 años de canto social.” La Jornada, July 13, 2007. http://www.jornada.unam.mx/2007/07/13/index.php?section =espectaculos\&article=a11n1esp.

—_ "Hoy, Gabino Palomares presentará su Historia cotidiana en la sala Ollin Yoliztli." La Jornada, March 22, 2001. http:/www.jornada.unam.mx/2001/03/22/07an1esp.html.

Díaz, Clara. Sobre la guitarra, la voz. La Habana: Editorial Letras Cubanas, 1994.

Díaz, Claudio. "The Nuevo Cancionero Movement: A Change of Paradigm in Argentine Folklore.” In $A$ Latin American Music Reader: Views from the South, edited by Javier F. León and Helena Simonett, 279-302. Urbana: University of Illinois Press, 2016.

Dillon, Lorna. Violeta Parra: Life and Work. Rochester: Tamesis Books, 2017.

Dunn, Christopher. Brutality Garden: Tropicália and the Emergence of a Brazilian Counterculture. Chapel Hill, NC: University of North Carolina Press, 2001.

Fairley, Jan. "Alive and Performing in Latin America: Review.” Popular Music 7, no. 1 (January 1988): 105-110. https://doi.org/10.1017/S0261143000002609.

- Living Politics, Making Music: The Writings of Jan Fairley. Edited by Simon Frith, Stan Rijven, and Ian Christie. Burlington, VT: Ashgate, 2014.

Feldman, Heidi. Black Rhythms of Peru: Reviving African Musical Heritage in the Black Pacific. Middletown: Wesleyan University Press, 2006.

Frischmann, Donald H. "Desarrollo y florecimiento del teatro mexicano: siglo XX." Teatro: revista de estudios teatrales 2 (1992): 53-59.

González Lucini, Fernando. Yla palabra se hizo música: La canción de autor en España. Madrid: Fundación Autor, 2006.

Gonzalez, Mike. "April in Managua: The Central American Peace Concert Popular Music.” Popular Music 6, no. 2 (May 1987): 247-249. https://doi.org/10.1017/S0261143000006061.

Hernández, David. "Nace el Frente Democrático Revolucionario.” La Opinión, July 16, 2005, 7A.

Horrigan, Alice. “New Song: New Political Song?” The Valley Advocate, July 28, 1986, 8.

Jaber F, Sergio. Programa del Primer Festival del Canto Nuevo Latinoamericano. México, 1982.

Juárez, Camila. "Popular Music and the Avant-Garde in Uruguay: The Second Canto Popular Generation in the 1970s." In The Militant Song Movement in Latin America: Chile, Uruguay, and Argentina, edited by Pablo Vila, 121-140. Lanham, MD: Lexington Books, 2014. 
Karam, Tanius. "Notas para pensar la Nueva Canción mexicana: De Los Folkloristas a Alejandro Filio.” Humania del Sur 9, no. 16 (January-June 2014): 27-39.

Karush, Matthew B. "Indigenous Argentina and Revolutionary Latin America: Mercedes Sosa and the Multiple Meanings of Folk Music." In Musicians in Transit: Argentina and the Globalization of Popular Music, 142-178. Durham: Duke University Press, 2017.

Krauze, Enrique. “La dictadura perfecta.” Letras Libres, November 12, 2012. http://www.letraslibres.com/mexico-espana/la-dictadura-perfecta.

López, Isaac. "La 'canción protesta' en Venezuela: Una aproximación a su origen y auge (1967-1977).” Humania del Sur Año 9, no. 16 (January-June 2014): 65-77.

Madrid, Alejandro. Music in Mexico: Expressing Music, Expressing Culture. New York: Oxford University Press, 2013: 115.

Marsh, Hazel. Hugo Chávez, Alí Primera and Venezuela: The Politics of Music in Latin America. London: Palgrave Macmillan, 2016. https://doi.org/10.1057/978-1-137-57968-3.

McSherry, J. Patrice. Chilean New Song: The Political Power of Music, 1960s-1973. Philadelphia: Temple University Press, 2015.

Messinger Cypess, Sandra. La Malinche in Mexican Literature from History to Myth. Austin: University of Texas Press, 1991.

Molinero, Carlos, and Pablo Vila. "Atahualpa Yupanqui: The Latin American Precursor of the Latin American Song Movement.” In The Militant Song Movement in Latin America: Chile, Uruguay, and Argentina, edited by Pablo Vila, 163-192. Lanham, MD: Lexington Books, 2014.

—. "A brief history of the militant song movement in Argentina" In The Militant Song Movement in Latin America: Chile, Uruguay, and Argentina, edited by Pablo Vila, 193-228. Lanham, MD: Lexington Books, 2014.

Moore, Robin. Music and Revolution: Cultural Change in Socialist Cuba. Berkeley: University of California Press, 2006.

—. "Transformations in Cuban Nueva Trova," in Ethnomusicology 47, no. 1 (2003): 1-41. https://doi.org/10.2307/852510.

Morris, Nancy. "New Song in Chile: Half a Century of Musical Activism." In The Militant Song Movement in Latin America: Chile, Uruguay, and Argentina, edited by Pablo Vila, 19-44. Lanham, MD: Lexington Books, 2014.

Ojeda, Martha. Nicomedes Santa Cruz: Ecos de Africa en Perú. Woodbridge: Tamesis, 2003.

Ojeda, Salvador. "Panorama del Canto Nuevo en México," Diálogos: artes, letras, ciencias humanas 15, no. 2 (March-April 1979): 23-29.

Hernandez, Deborah Pacini, Héctor D. Fernández L'Hoeste, and Eric Zolov, eds. Rockin' Las Américas: The Global Politics of Rock in Latin/o America. Pittsburgh: University of Pittsburgh Press, 2004.

Reyes Matta, Fernando. "The New Song and Its Confrontation in Latin America." In Marxism and the Interpretation of Culture, edited by Cary Nelson and Lawrence Grossberg, 448-449. Urbana: University of Illinois Press, 1988.

Rodríguez Musso, Osvaldo. La nueva canción chilena: continuidad y reflejo. La Habana: Casa de las Américas, 1988.

Sturman, Janet. The Course of Mexican Music. New York: Routledge, 2016. 
Torres Blanco, Roberto. "Canción protesta: definición de un nuevo concepto historiográfico," in Cuadernos de Historia Contemporánea 27 (2005): 223-246.

Trigo, Abril. "Modern Foundations of Uruguayan Popular Music" The Militant Song Movement in Latin America: Chile, Uruguay, and Argentina, edited by Pablo Vila, 97-120. Lanham, MD: Lexington Books, 2014.

Tumas-Serna, Jane. "The Nueva Canción Movement and Its Mass-Mediated Performance Context." Latin American Music Review 13, no. 2 (1992): 139-157.

Ureña, Juan Carlos. "The Mockingbird Still Calls for Arlen: Central American Songs of Rebellion 1970_ 2010," in Song and Social Change, edited by Lauren Shaw, 49-76. New York: Lexington Books, 2013.

Velasco, Jorge. El canto de la tribu. México D.F.: Conaculta, 2004.

Villanueva, René. Cantares de la memoria: Recuerdos de un folklorista. 25 años de historia del grupo Los Folkloristas: alma y tradición de la música popular mexicana. México, D.F.: Planeta, 1994.

Wallis, Roger, and Krister Malm. Big Sounds from Small Peoples: The Music Industry in Small Countries. New York: Pendragon Press, 1984.

\begin{abstract}
During the second half of the twentieth century, there were no spectacular events in Mexico-civil wars, military dictatorships, or revolutions - capable of fracturing the social, political, or cultural structures of the country. The absence of these culturally traumatic events positioned Mexican protest songs in the periphery of the affective narrative of the nation. The story of modern Mexican troubadours was, nevertheless, a story of resistance whose heroes - the singers, songwriters, and performers—spent the decades between 1960 and 1990 denouncing poverty and corruption, condemning governmental violence, marching side by side with students, activists, women, workers, and peasants, supporting civil rights and grassroots movements both nationally and internationally with their songs. The story of these musicians has remained unknown for too long. This article attempts to reignite academic interest in this story with the goal of encouraging future critical and theoretical studies regarding socially-engaged Mexican singers and songwriters from the 1960s through the 1990s. It focuses on the life and work of one of the main exponents of the Mexican protest song, singer-songwriter Gabino Palomares (b. 1950). It offers a brief historical analysis of the Mexican Canto Nuevo movement and establishes a much-needed chronology of Palomares's work, essential to our understanding of the contemporary cultural history of Mexico.
\end{abstract}

